\title{
MANTLE XENOLITHS AND NEW CONSTRAINTS ON THE ORIGIN OF ALKALINE ULTRAPOTASSIC ROCKS FROM THE ALTO PARANAÍBA AND GOIÁS IGNEOUS PROVINCES, BRAZIL
}

\author{
J.C. Gaspar ${ }^{1}$, A.L.N. Araujo ${ }^{2}$, R.W. Carlson ${ }^{3}$, S.E. Sichel ${ }^{2}$, J.A. Brod ${ }^{1}$, P.B. Sgarbi ${ }^{4}$ and J.C.M. \\ Danni ${ }^{1}$ \\ ${ }^{1}$ Universidade de Brasília, Brazil; ${ }^{2}$ Universidade Federal Fluminense, Brazil; ${ }^{3}$ Carnegie Institution of Washington, USA; \\ ${ }^{4}$ Universidade Federal de Belo Horizonte, Brazil
}

\section{INTRODUCTION}

The Alto Paranaíba and Goiás Alkaline Provinces, located in southern Brazil (Figure 1) are composed mainly by kamafugites (Danni \& Gaspar 1994; Sgarbi et al. 1995; Gibson et al. 1995; Sgarbi 1998; Araujo et al. 2001a, 2001b). In the Alto Paranaíba Province the kamafugites are associated with kimberlites (Araujo et al. 2001a) and carbonatites (Brod et al. 2000).

The Alto Paranaíba Province magmas intruded the Neoproterozoic Brasília Mobile Belt, while the Goiás Province is located in the limit between the Brasília Belt and the Paraná Basin. Some recent works have proposed to group the two provinces under the designation of "Minas Gerais-Goiás Province", including all the respective alkaline occurrences. However, the nature and the relationship between the provinces have not been studied in enough detail yet. In this work, we present new geochemical and isotopic data that point to different lithospheric mantle sources and different evolution processes, arguing against the unification of the two provinces. Araujo et al. (2001a) identified, on the basis of Re-Os isotopic composition, different mantle sources for kimberlites and kamafugites of the Alto Paranaíba Province. The chemistry and thermobarometry of low-T spinel and garnet peridotite xenoliths from the Alto Paranaíba Province were initially studied by Carvalho (1997). Danni et al. (1994) presented thermobarometric data (ca. $850^{\circ} \mathrm{C}, 14 \mathrm{~kb}$ ) for the garnet spinel peridotites from the Paraúna area, in the Goiás Province.

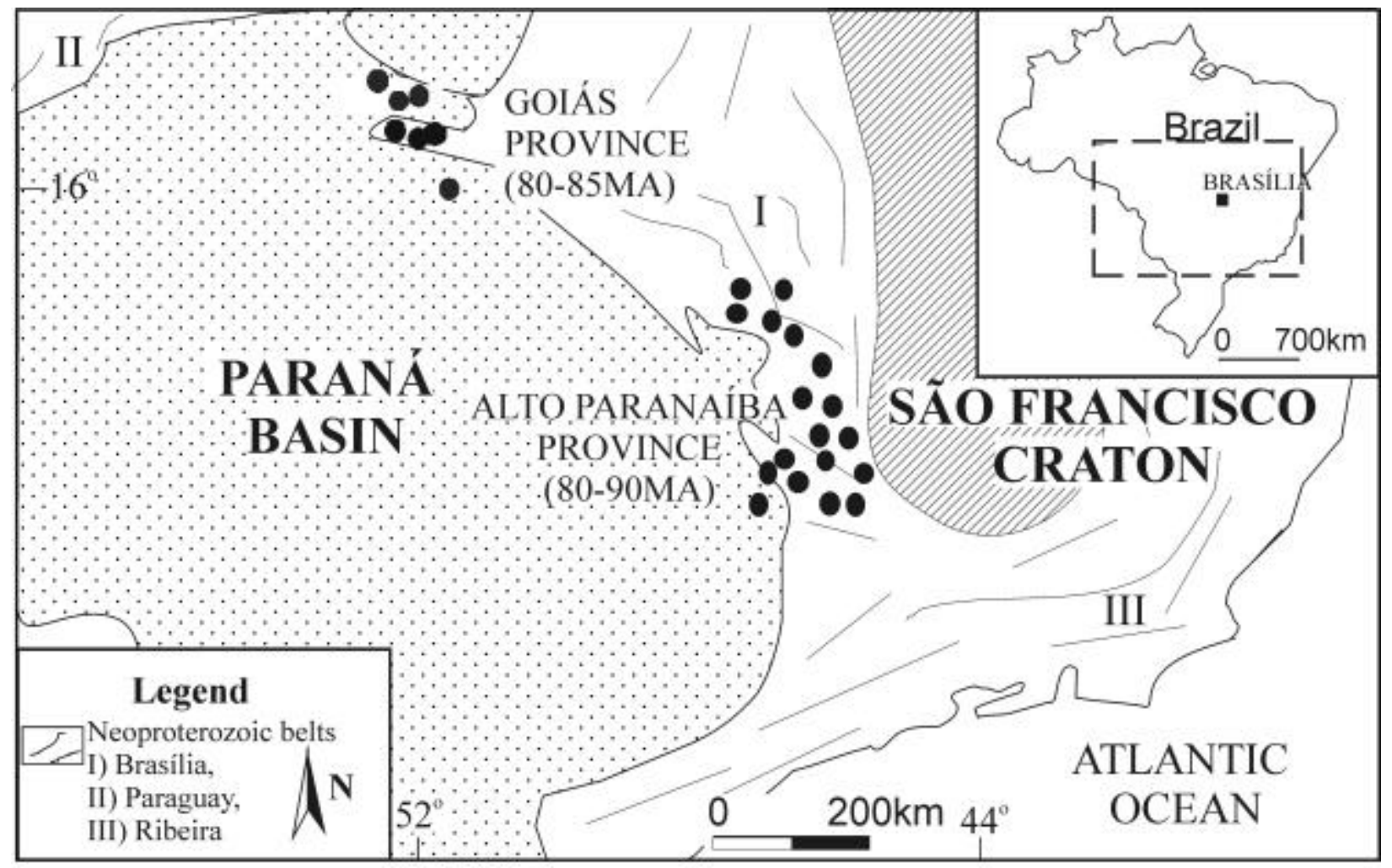

Fig. 1: Location of Alto Paranaiba and Goiás Province. Modified from Gibson et al. 1995. 
The Alto Paranaíba garnet and spinel lherzolite xenoliths are small $(4-6 \mathrm{~cm})$, medium- to coarsegrained, and show a slightly strained texture. The Paraúna spinel lherzolite xenoliths are small (up to 7 $\mathrm{cm}$ ), coarse-grained, and have polygonal texture. All samples correspond to low-temperature peridotites (Carvalho 1997; Danni et al. 1994).

\section{ANALYTICAL PROCEDURES}

The xenoliths were manually and carefully separated from the host rock (kimberlites and kamafugites) and crushed into an alumina vessel. Aliquots from the powdered sample were separated for major element analyses, carried out by ICP spectrometry, and for determination of the Re-Os isotopic composition, by negative thermal ionization mass spectrometry. Procedures for Re-Os separation follow Carlson et al. (1999). Rb, Sr, Sm, and Nd compositions of kamafugites were determined by MC-ICP-MS and TIMS as described by Araujo et al. (2001). All isotope analyses were carried out at the Carnegie Institution of Washington.

\section{GEOCHEMISTRY}

Table 1 shows some representative major and trace element analyses of the studied spinel and garnet peridotites.

\section{MAJOR ELEMENTS}

The Alto Paranaíba peridotite xenoliths exhibit high $\mathrm{MgO}$ content $(\mathrm{mg} \#=89-91)$ and low $\mathrm{Ab}_{2} \mathrm{O}_{3}, \mathrm{CaO}$ and $\mathrm{Na}_{2} \mathrm{O}$, when compared with Paraúna peridotite xenoliths (Figure 2). In the Paraúna peridotite xenoliths (mg\# roughly constant around 89 ), the very high $\mathrm{Al}$, $\mathrm{Ca}, \mathrm{Na}$ and $\mathrm{Ti}$ oxide contents could be indicative of metasomatic introduction of these elements. $\mathrm{FeO}$ and $\mathrm{Cr}$ contents are similar in both xenolith groups (ca. $8.0 \mathrm{wt} \%$ and $2500 \mathrm{ppm}$, respectively). The $\mathrm{TiO}_{2}$ contents vary from $0.09-0.24 \mathrm{wt} \%$ in the Alto Paranaíba xenoliths and from $0.15-3.17 \mathrm{wt} \%$ in the Paraúna xenoliths.

\section{ISOTOPIC COMPOSITIONS}

\section{Re-Os isotopes in mantle xenoliths}

Tables 1 and $\mathbf{2}$ summarize the isotopic data obtained in this work.

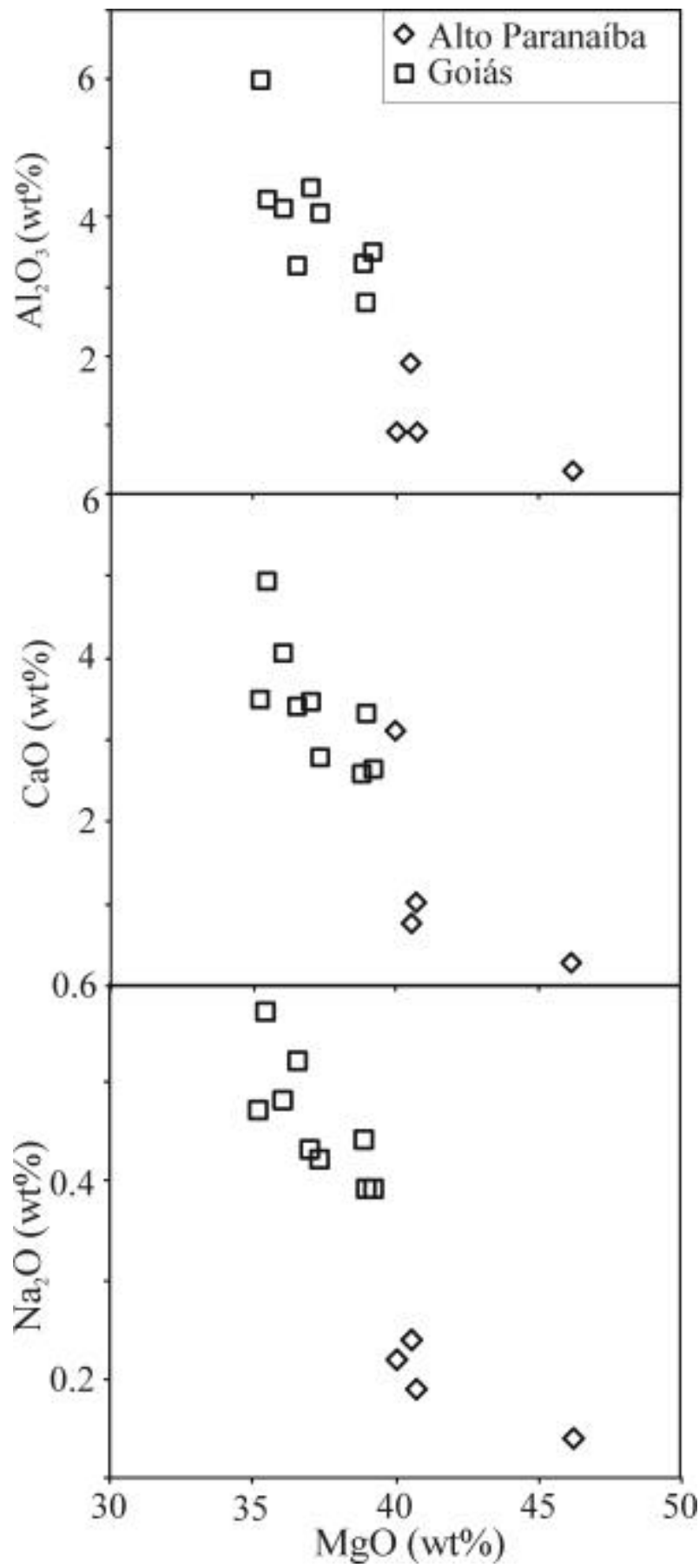

Figure 2: Major elements variation diagrams for the Alto Paranaíba and Goiás (Paraúna) peridotite xenolhits.

The Alto Paranaíba garnet and spinel lherzolite xenoliths have very low ${ }^{188} \mathrm{Os} /{ }^{187}$ Os ratios (0.109 to 0.115 , Figure 3), similar to those of ancient lithospheric peridotites from Kaapvaal, Wyoming and Siberian cratons (Carlson and Irvinig 1994; Pearson et al. 1995; Carlson et al. 1998), and yield Re-depletion model ages varying from 1.9 to $2.7 \mathrm{Ga}$. This indicates the presence of Paleoproterozoic/Archean lithosphere 
underneath the Neoproterozoic Brasília Mobile belt, where the kimberlites intruded. The spinel lherzolites from Goiás Province (Paraúna) show two different ${ }^{188} \mathrm{Os} /{ }^{187} \mathrm{Os}$ groups Figure 3). One has ${ }^{188} \mathrm{Os} /{ }^{187} \mathrm{Os}$ between 0.121 and 0.122 , with Re-depletion model ages ranging from 1.0 to $1.2 \mathrm{Ma}$. The second group has very high ${ }^{188} \mathrm{Os} /{ }^{187}$ Os (between 0.126 and 0.129 ), similar to those observed in younger rift-related spinel peridotites (Meisel et al. 1996).

\section{Isotopic composition of kamafugites and kimberlites}

The Santo Antônio da Barra kamafugites, in the Goiás Province, have $\mathrm{Sr}$ and $\mathrm{Nd}$ isotope signatures which completely overlap those observed for the Tristan/ Walvis Ridge and for the high-Ti Paraná basalts (Figure 4). The Alto Paranaíba kamafugites have $\mathrm{Pb}$ isotopic signatures overlapping the Tristan/ Walvis Ridge basalts, but their $\mathrm{Sr}$ and $\mathrm{Nd}$ isotopic ratios are slightly more enriched (Araujo et al. 2001). The ${ }^{188} \mathrm{Os} /{ }^{187} \mathrm{Os}$ in kamafugites of the Goiás Province are higher (ca. 0.15) than those of the Alto Paranaíba kamafugites (ca. 0.13), probably indicating that their sources were subjected to different evolution process.

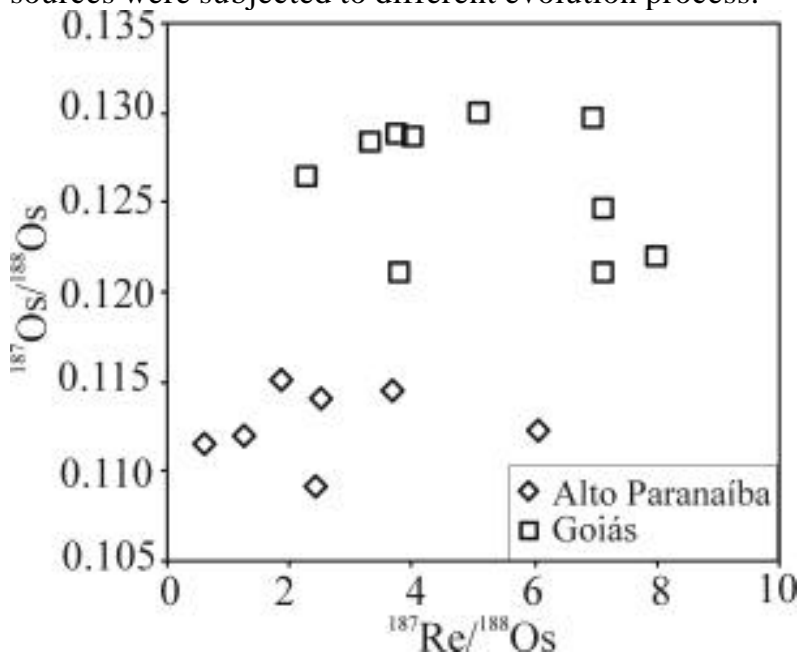

Figure 3: ${ }^{187} \mathrm{Re} /{ }^{188} \mathrm{Os}$ versus ${ }^{187} \mathrm{Os} /{ }^{188} \mathrm{Os}$ isotopic composition for the Alto Paranaíba and Goiás (Paraúna) peridotites

The $\mathrm{Pb}, \mathrm{Sr}$, and $\mathrm{Nd}$ signatures of kimberlites from the Alto Paranaíba Province are intermediate between the fields of South African kimberlites and orangeites, partially overlapping the former (Araujo et al. 2001).

\section{DISCUSSION}

In spite of their geographical proximity and lithologic similarities, the Alto Paranaíba and Goiás provinces, show isotopic differences that are difficult to reconcile with a single origin and evolution. The lithosphere under the Alto Paranaíba Province contains a Re-Os signature that is similar to ancient cratonic lithosphere, whereas the isotopic signature of peridotite xenoliths in the Goiás Province indicates a younger lithosphere. Furthermore, kamafugites from Alto Paranaíba and Goiás Provinces show differences in ${ }^{187} \mathrm{Os} /{ }^{188} \mathrm{Os}$, which could be indicating independent evolution of their respective mantle sources.

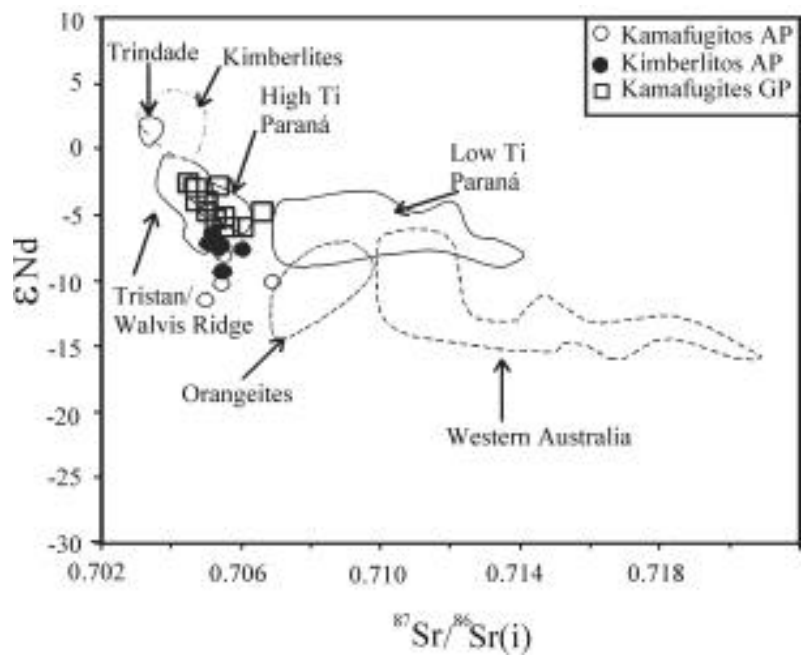

Figure $4: \varepsilon_{\mathrm{Nd}}$ versus ${ }^{87} \mathrm{Sr} /{ }^{86} \mathrm{Sr}$ variation diagram. Kamafugites and kimberlites from the Alto Paranaíba Alkaline Province from Araujo et al. (2001), Kimberlites and orangeites fields from Mitchell (1995), Paraná basalts from Hawkeswork et al . (1988), Mantovani et al. (1985), and Piccirillo et al. (1989), and Tristan da Cunha from O’Nions et al. (1977).

The occurrence of Paleoproterozoic to Archean Redepletion model ages in peridotite xenoliths of the Alto Paranaíba Province indicates that at least some of the lithosphere underneath is composed of preserved remnants of the São Francisco Craton.

\section{ACKNOWLEDGEMENTS}

J.C.G and J.A.B. acknowledge research grants from $\mathrm{CNPq}$ - Brazilian Council for Research and Development.

\section{REFERENCES}

Araujo, A.L.N., Carlson, R.W., Gaspar, J.C., Bizzi, L.A., 2001a. Petrology of kimberlites and kamafugites from the Alto Paranaíba Igneous Province. Cont. Min. Petrol. 142, 166-177.

Araujo, A.L.N., Gaspar, J.C., Carlson, J.C., Sichel, S.E., Costa, V.S., Teixeira, N.A., 2001b. Pb, Nd, Sr, and 
Os isotopic systematics of Brazilian cretaceous potassic rocks. Rev. Bras, Geoc. 31: 163-168.

Brod, J.A., Gibson, S.A., Thompson, R.N., Junqueira-Brod, T.C., Seer, H.J., Moraes, L.C., Boaventura, G.R., 2000. The kamafugite-carbonatite association in the Alto Paranaíba Igneous Province (APIP), southeastern Brazil. Ver. Bras. Geoc., 30:404-408.

Carvalho, B.C., 1997. Petrology of mantle xenolihts from the Alto Paranaíba Province, Minas Gerais and Goiás. Ph.D. Thesis, Brasília Univ. Brasília, Brazil (in Portuguese).

Carlson, R.W., IRVINIG, A.J., 1994. Depletion and enrichment history of subcontinental lithospheric mantle: an $\mathrm{Os}, \mathrm{Sr}, \mathrm{Nd}$ and $\mathrm{Pb}$ isotopic study of ultramafic xenoliths from the Wyoming Craton. Earth Planet. Sci. Lett., 126:457-472.

Carlson, R.W., Irvinig, A.J., Heam, B.C. Jr., 1998. Peridotite xenoliths from the Willians kimberlite, Montana: Implications for delamination of the Wyoming Craton lithosphere. Final Proc. Int. Kimb. Conf. , Cape Town, South Africa, pp. 132-134.

Carlson, R.W., Pearson, D.G., Boyd, F.R., Shirey, S.B., Irvine, G., Menzies, A.H., Gurney, J.J., 1999. Re-Os systematics of lithospheric peridotites: implications for lithosphere formation and preservation. Final Proc. Int. Kimb. Conf. , Cape Town, South Africa, pp. 99-108.

Danni, J.C.M., Vasconcelos A.C.B.C. \& Gaspar, J.C., 1994. Spinel-garnet lherzolite and spinel lherzolite xenoliths from the northeastern border of the Paraná Basin, Brazil. Ext. Abstr. Of the International Symp. on the Physics and Chemistry of the Upper Mantle. São Paulo. pp 14-16.

Gibson, S.A., Thompson, R.N., Leonardos, O.H., Dickin, A.P., Mitchell, J.G., 1995. The late Cretaceous impact of the Trindade mantle plume: evidence from large-volume, mafic, potassic magmatism in SE Brasil. Journal of Petrology, 36: 189-229.

Hawkesworth, C.J., Mantovani, S.M., Peate, D., 1988. Lithosphere remobilization during Paraná CFB magmatism. J. of Petrol., Special Lithosphere Issue, pp. 205-223.

Meisel, T., Walker, R.J., Morgan, J.W., 1996. The osmium isotopic composition of the Earth's primitive upper mantle. Nature 383: 517-520.

O’Nions, R.K., Hamilton, P.J., Evesen, N.M., 1977. Variations in ${ }^{143} \mathrm{Nd} /{ }^{144} \mathrm{Nd}$ and ${ }^{87} \mathrm{Sr} /{ }^{88} \mathrm{Sr}$ ratios in oceanic basalts. Earth Planet. Sci. Lett., 34:22.

Pearson, D.G., Shirey, S.B., Carlson, R.W., Boyd, F.R., Pokhilenko, N.P., Schimizu, N, 1995. Re-Os, Sm-Nd and $\mathrm{Rb}-\mathrm{Sr}$ isotope evidence for thick Archaean lithospheric mantle beneath the Siberian craton modified by multi-stage metasomatism. Geochim Cosmochim Acta 59: 959-977.

Piccirillo, E.M., Civetta, L., Petrini, R., Longinelli, A., Bellieni, G., Comin-Chiaramonti, P., Marques, L.S., Melfi, A.J. 1989. Regional variations in Paraná flood basalts (southern Brazil): evidence for subcontinental mantle heterogeneity and crustal contamination. Chem. Geol., 75:103-122.

Sgarbi, P.B.A. 1998. Mineralogy and Petrology of the kamafugites from the Santo Antônio da Barra region, southwest Goiás (In Portuguese). PhD Thesis, Brasília Univ. Brasília, Brazil (in Portuguese).

Contact: JC Gaspar, Universidade de Brasília, Campus Darcy Ribeiro, Brasília, DF, 70910-900, Brasil, E-mail: gasp@unb.br 
Table 1: Major and Re-Os representative analyses of mantle xenoliths from Alto Paranaíba and Goiás Province (Paraúna region).

\begin{tabular}{|c|c|c|c|c|c|c|c|c|}
\hline $\begin{array}{l}\text { Location } \\
\text { Type }\end{array}$ & \multicolumn{3}{|c|}{$\begin{array}{l}\text { Alto Paranaíba xenolhits } \\
\text { gr-Iherzoliths }\end{array}$} & \multicolumn{3}{|c|}{$\begin{array}{l}\text { Paraúna xenoliths } \\
\text { Sp-Iherzolits }\end{array}$} & \multirow[b]{2}{*}{ IP-5 } & \multirow[b]{2}{*}{ IP-9 } \\
\hline Sample & AP-2 & AP-3 & AP- 6 & AP-8 & $\mid \mathrm{P}-1$ & IP-2 & & \\
\hline $\mathrm{SiO}_{2}$ & 43,23 & 38,89 & 41,03 & 39,75 & 44,18 & 43,54 & 43,07 & 43,98 \\
\hline $\mathrm{TiO}_{2}$ & 0,09 & 0,12 & 0,2 & 0,24 & 0,18 & 0,19 & 0,15 & 0,2 \\
\hline $\mathrm{Al}_{2} \mathrm{O}_{3}$ & 1,88 & 0,34 & 0,9 & 0,91 & 4,4 & 2,74 & 3,49 & 4,1 \\
\hline $\mathrm{Fe}_{2} \mathrm{O}_{3}$ & 1,3 & 1,04 & 1,67 & 1,64 & 1,81 & 1,82 & 1,61 & 1,73 \\
\hline $\mathrm{FeO}$ & 5,54 & 7,18 & 6,45 & 10,25 & 6,64 & 6,76 & 7,08 & 6,36 \\
\hline $\mathrm{MnO}$ & 0,12 & 0,12 & 0,15 & 0,19 & 0,15 & 0,14 & 0,15 & 0,15 \\
\hline $\mathrm{MgO}$ & 40,55 & 46,21 & 40,74 & 40 & 37,05 & 39 & 39,26 & 36,1 \\
\hline $\mathrm{CaO}$ & 0,76 & 0,28 & 1,03 & 3,12 & 3,46 & 3,3 & 2,64 & 4,05 \\
\hline $\mathrm{Na}_{2} \mathrm{O}$ & 0,24 & 0,14 & 0,19 & 0,22 & 0,43 & 0,39 & 0,39 & 0,48 \\
\hline $\mathrm{K}_{2} \mathrm{O}$ & 1,19 & 0,13 & 0,89 & 0,13 & 0,07 & 0,15 & 0,17 & 0,16 \\
\hline $\mathrm{P}_{2} \mathrm{O}_{5}$ & 0,03 & 0,05 & 0,05 & 0,18 & 0,03 & 0,04 & 0,05 & 0,04 \\
\hline PF & 4,23 & 4,94 & 5,82 & 2,67 & 1,23 & 1,87 & 1,87 & 2,4 \\
\hline Total & 99,16 & 99,44 & 99,12 & 99,3 & 99,63 & 99,94 & 99,54 & 99,75 \\
\hline $\mathrm{Ni}$ & 2390 & 3115 & 2545 & 2685 & 2295 & 2600 & 2365 & 2025 \\
\hline $\mathrm{Cr}$ & 6200 & 202 & 2745 & 1445 & 2465 & 1470 & 1710 & 2405 \\
\hline \#Mg & 91 & 91 & 90 & 89 & 89 & 89 & 89 & 89 \\
\hline $\operatorname{Re}(p p t)$ & 1005 & 3278 & 2060 & 1565 & 1038 & 3363 & 3077 & 3181 \\
\hline Os(ppt) & 8126 & 2608 & 4087 & 2983 & 1241 & 2023 & 2076 & 3007 \\
\hline${ }^{187} \mathrm{Re} /^{188}$ Os & 0,595 & 6,046 & 2,423 & 2,524 & 4,031 & 8,007 & 7,136 & 5,101 \\
\hline${ }^{187} \mathrm{Os} /{ }^{188}$ Os & 0,11157 & 0,11228 & 0,10915 & 0,11411 & 0,12866 & 0,12186 & 0,12097 & 0,12993 \\
\hline${ }^{187} \mathrm{Os} /{ }^{188} \mathrm{Os}(\mathrm{i})$ & 0,11073 & 0,10371 & 0,10572 & 0,11053 & 0,12295 & 0,11051 & 0,11086 & 0,12270 \\
\hline$\gamma \mathrm{Os}(\mathrm{i})$ & $-13,6$ & $-19,0$ & $-17,5$ & $-13,7$ & $-4,0$ & $-13,7$ & $-13,5$ & $-4,2$ \\
\hline $\mathrm{T}_{\mathrm{RD}}(\mathrm{Ga})$ & 2,4 & 2,3 & 2,7 & 2,0 & 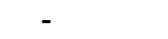 & 1,0 & 1,1 & - \\
\hline
\end{tabular}

Table 2: Isotopic representative analyses of kamafugites from Goiás Province Location Santo Antônio da Barra

\begin{tabular}{|c|c|c|c|c|c|}
\hline ample & SAB-2 & SAB-5 & SAB-6 & IPK-3 & IPK-4 \\
\hline $\mathrm{Rb}(\mathrm{ppm})$ & 239 & 39,71 & 106,7 & 58,68 & 68,90 \\
\hline Sr.(ppm) & 1136 & 1199 & 1429 & 1659 & 1353 \\
\hline $\begin{array}{l}{ }^{87} \mathrm{Rb} /{ }^{86} \mathrm{Sr} \\
\mathrm{O}\end{array}$ & 0,6077 & 0,0958 & 0,2159 & 0,1023 & 0,1473 \\
\hline & 0,705526 & 0,704986 & 0,705406 & 0,705048 & 0,705039 \\
\hline 烈 $\mathrm{Sr} r^{86} \mathrm{Sr}(i)$ & 704792 & 0,704870 & 0,7051 & 0,704924 & 0,704861 \\
\hline $\mathrm{Sm}(\mathrm{ppm})$ & 6,48 & 10,42 & 15,93 & 17,03 & 16,60 \\
\hline & 82,49 & 68, & & & 102,89 \\
\hline 年7 $\mathrm{mm}^{144} \mathrm{Nd}$ & 0,1207 & 0,0924 & $0,0 \varsigma$ & 0,0975 & 0,0975 \\
\hline $143{ }^{143} \mathrm{Nd}^{144} \mathrm{Nd} 0,512356$ & 0,512443 & 0,512481 & 0,512420 & 0,512377 & \\
\hline $1433 \mathrm{Nd} /{ }^{144} \mathrm{Nd}(\mathrm{i})$ & 0,512289 & 0,512392 & 0,512428 & 0,512366 & 0,512323 \\
\hline $\mathrm{Na}(\mathrm{i})$ & & -3 & & -3 & \\
\hline & 1,36 & 0,94 & 0,92 & 1,01 & 1,07 \\
\hline & & 51 & 23 & 873 & 248 \\
\hline Os (ppt) & 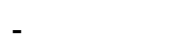 & 5713 & 3723 & 8696 & 12462 \\
\hline${ }^{187} \mathrm{Re} /{ }^{188} \mathrm{Os}$ & - & 0,043 & 0,298 & 0,486 & 0,096 \\
\hline${ }^{187} \mathrm{Os} /{ }^{188} \mathrm{Os}$ & - & 0,14523 & 0,14568 & 0,15875 & 0,14256 \\
\hline 187 $\mathrm{Os} /{ }^{188} \mathrm{Os}(\mathrm{i})$ & 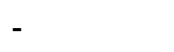 & 0,14517 & 0,14526 & 0,15806 & 0,14242 \\
\hline Yos (i) & & 13,325793 & 13,394649 & & 11,18286 \\
\hline & & $-2,3762076$ & $-2,3891907$ & & $-1,9735$ \\
\hline
\end{tabular}

